RODRIGUES, Danilo Pontes. Doutrina Bush e violência em In the Shadow of no Towers de Art Spiegelman. Domínios da imagem, v. 13, n. 24, p. 122-156, jan./jun. 2019.

Recebido em 10/7/2019 e aprovado em 10/10/2019

\title{
DOUTRINA BUSH E VIOLÊNCIA EM IN THE SHADOW OF NO TOWERS' DE ART SPIEGELMAN
}

\section{BUSH DOCTRINE AND VIOLENCE IN IN THE SHADOW OF NO TOWERS OF ART SPIEGELMAN}

Danilo Pontes Rodrigues*

Resumo: O presente artigo buscou analisar questões geradas pelos atentados terroristas do dia 11 de setembro de 2001, assim como os seus desdobramentos, a partir de questões apresentadas pela história em quadrinhos In the shadow of no towers do quadrinista Art Spiegelman. Além de aspectos abordados a partir das medidas do governo Bush, o artigo contempla as questões quanto ao USA PATRIOT ACT, assim como as privações das liberdades individuais, processos que somente foram possíveis graças ao forte abalo que a sociedade passou após os atentados terroristas. O trabalho também contempla como Spiegelman abordou as guerras da Afeganistão e do Iraque, promovidas pelo governo estadunidense, criticando a violência promovida por este governo.

Palavras-chave: História; Quadrinhos; Art Spiegelman; Doutrina Bush; Violência.

Abstract: The present article aimed to analyze issues generated by the terrorist attacks of September 11, 2001, as well as their consequences, based on questions presented by the comic book Art Spiegelman's In the shadow of no towers. In addition to aspects addressed from the Bush administration's measures, the article addresses issues regarding the USA PATRIOT ACT, as well as the deprivation of individual freedoms, processes that were only possible thanks to the strong disruption society experienced after the terrorist attacks. The paper also looks at how Spiegelman approached the Afghanistan and Iraq wars promoted by the US government, criticizing the violence promoted by this government.

Key-words: History; Comics; Art Spiegelman; Bush Doctrine; Violence.

\footnotetext{
1 Traduzido como À sombra das torres ausentes publicado pela editora Companhia das Letras.

- Mestre em História Social pela Universidade Estadual de Londrina - PPGHS UEL, Professor substituto de História na rede municipal de Itajaí, Email: danilorodrigues2702@gmail.com
} 
RODRIGUES, Danilo Pontes. Doutrina Bush e violência em In the Shadow of no Towers de Art Spiegelman. Domínios da imagem, v. 13, n. 24, p. 122-156, jan./jun. 2019.

Os ataques terroristas do dia 11 de setembro de 2001 foram eventos que marcaram todo o mundo, em específico, os Estados Unidos. Não apenas pelos cidadãos estadunidenses mortos, o atentado foi um ataque ocorrido dentro do território nacional americano e determinou muitas decisões políticas, seja no tocante à legislação interna, ou às relações internacionais do governo americano. Se os números "911"2 já tinham uma natureza de emergência atrelada a eles, após os atentados, os números ganharam um novo significado.

Além de medidas unilaterais por parte do governo estadunidense, pode-se observar a criação de um sentimento de desconfiança persistente na população norte-americana. O medo de outro atentado terrorista iminente se mostrou um terreno fértil para as decisões do governo, que aprovou, junto ao congresso, o USA PATRIOT $\mathrm{ACT}^{3}$, também conhecido como ato patriota, sancionado pelo presidente George W. Bush, em 26 de outubro de 2001, e acabou por restringir as liberdades individuais. Receio da sociedade que também colaborou para que o governo estadunidense investisse em duas guerras num período de dois anos.

Assim, considerando o contexto o quadrinista estadunidense Art Spiegelman publicou, no período de 2002 a 2004, uma série de pranchas contendo histórias em quadrinhos $(H Q)^{4}$, estas que foram intituladas como $\grave{A}$ sombra das torres ausentes ou no original In the shadow of no towers, trabalho encomendado pelo semanário alemão Die Zeit, conforme o autor diz na introdução do sua obra (SPIEGELMAN, 2004).

\footnotetext{
2 Nos Estados Unidos, o número telefônico para atender situações de emergência é o "911"; a data dos atentados, coincidentemente é o "9/11", considerando que neste país se tem por costume colocar os dias antes dos meses ao representar as datas.

3 Abreviação do nome expandido Uniting and Strengthening America by Providing Appropriate Tools Required to Intercept and Obstruct Terrorism Act of 2001.

${ }^{4}$ A partir deste momento será utilizada a abreviação HQs para referir ao termo História em Quadrinhos.
} 
RODRIGUES, Danilo Pontes. Doutrina Bush e violência em In the Shadow of no Towers de Art Spiegelman. Domínios da imagem, v. 13, n. 24, p. 122-156, jan./jun. 2019.

Imagem 1 - Capa da HQ In the Shadow of No Towers.

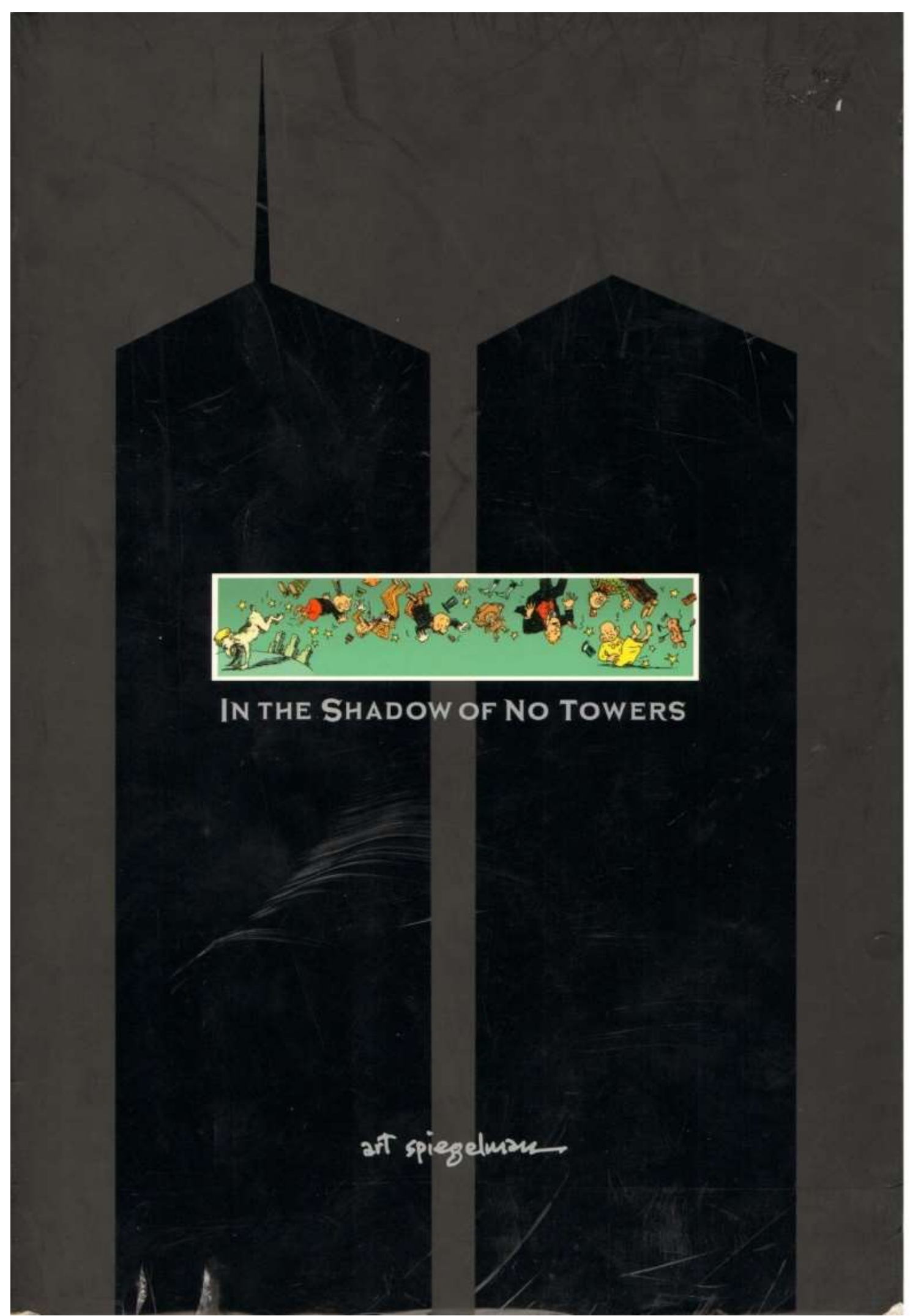

Fonte: Spiegelman (2004). 
RODRIGUES, Danilo Pontes. Doutrina Bush e violência em In the Shadow of no Towers de Art Spiegelman. Domínios da imagem, v. 13, n. 24, p. 122-156, jan./jun. 2019.

Spiegelman ficou famoso no meio das $H Q$ s por seu trabalho editorial na revista RAW e pela sua obra mais famosa MAUS (1986), que concedeu ao autor no ano de $1992^{5}$ o prêmio Pulitzer, publicado entre 1980 e 1991. Prêmio este que até então era destinado exclusivamente às obras literárias.

Assim, Spiegelman em In the shadow of no towers fez uma série de críticas ao governo Bush, também como às reações da sociedade estadunidense pós 11 de Setembro, principalmente pela falta de informação, medo exacerbado da comunidade dos Estados Unidos com a possibilidade de outros atentados terroristas, tal como a instrumentalização do governo ante aos acontecimentos.

No trabalho de dissertação, buscamos compreender as relações da sociedade estadunidense a partir da perspectiva de Spiegelman, em In the shadow of no towers. Analisando o acontecimento traumático dos atentados de 11 de setembro de 2001, optamos por interpretar as sombras partindo da perspectiva de Spiegelman por meio da ótica do psicólogo Carl Gustav Jung (2000), uma vez que o quadrinista critica as medidas tomadas pelo governo estadunidense, assim como a análise da capa escolhida pelo autor-Imagem 1 - capa onde podemos contemplar não somente as sombras das torres gêmeas, como também vários personagens de quadrinhos clássicos em queda livre no centro da mesma6 (RODRIGUES, 2017).

Portanto faremos, em um primeiro momento, um breve levantamento teórico sobre como os meios midiáticos se relacionam com o seu público e como as HQs se enquadram no meio. Posteriormente faremos considerações sobre o governo Bush e suas políticas, ao mesmo tempo, faremos uma relação com a HQ de Spiegelman. Optamos por apresentar aspectos específicos da

\footnotetext{
${ }^{5}$ Conforme pode-se constatar em 1992 The Winners and Finalists (PULITZER, 2016).

${ }^{6} \mathrm{Na}$ capa são retratados diversos personagens de HQs do final do século XIX e início do XX junto com título da $H Q$, expondo que as explosões desenterraram tais personagens, que passaram a assombrar um aturdido habitante do bairro, que são personagens de obras como Krazy Katz, Katzenjammer Kids, Hogan's Alley, Happy Hooligan, Kinder Kids, Little Nemo in slumberland, Upside Downs of Little Lady Lovekins and Old Man Muffaroo e Bringing Up father (SPIEGELMAN, 2004, the comic suplement). Personagens estes que podemos identificar também na Imagem 1 junto à prancha de desenho do autor. (RODRIGUES, 2017, pg. 78).
} 
RODRIGUES, Danilo Pontes. Doutrina Bush e violência em In the Shadow of no Towers de Art Spiegelman. Domínios da imagem, v. 13, n. 24, p. 122-156, jan./jun. 2019.

doutrina Bush, como os cerceamentos de liberdades individuais, as obstruções de direitos civis e o empreendimento de guerras pelo governo estadunidense, foram amplamente criticadas pela população, por intelectuais, por outros países e por Art Spiegelman.

\section{Consideração sobre cultura e mídia}

Muito se discutiu acerca da expressão que as HQs, assim como outras mídias, representaram para sociedade, e com a inserção do capitalismo no meio de produção cultural, como ficaria a relação do público com estes produtos midiáticos. Muitas vezes, partindo de certa interpretação dos escritos da Escola de Frankfurt?', em especial de Adorno e Horkheimer, alguns teóricos entendiam que, pelo consumo estético massificado, as pessoas tenderiam a aderir acriticamente os valores, sendo impostos de forma repetida e sedutora, incapacitando-se para superar a alienação, portanto, contribuindo para reproduzir e perpetuar a ideologia dominante e, por consequência, a própria estrutura social.

Contudo, o caráter dominador e alienante da indústria cultural, que as HQs poderiam estar englobadas, fora contestado por Umberto Eco (2006, p. 50) em seu livro Apocalípticos e Integrados, no qual o autor para compreender tal relação, parte-se da seguinte questão: ao considerar a estrutura intrínseca da nossa sociedade industrial com a mídia de massa, qual seria a forma em que poderiam ser transmitidos valores culturais nestes mesmos meios?

Para Umberto Eco, por mais que os burgueses administrem os meios de produção dos produtos de massa, não seriam eles os idealizadores de tais produtos, aí então o papel dos diretores e roteiristas de filmes, romancistas e, no caso das $H Q$ s, os desenhistas e roteiristas, poderiam criar materiais críticos

\footnotetext{
7 Escola de Frankfurt (em alemão: Frankfurter Schule) refere-se a uma escola de teoria social interdisciplinar neo-marxista, particularmente associada com o Instituto para Pesquisa Social da Universidade de Frankfurt. Muitos dos teóricos desta escola entendiam que a tradicional teoria marxista não poderia explicar adequadamente o desenvolvimento de sociedades capitalistas no século XX.
} 
RODRIGUES, Danilo Pontes. Doutrina Bush e violência em In the Shadow of no Towers de Art Spiegelman. Domínios da imagem, v. 13, n. 24, p. 122-156, jan./jun. 2019.

representando o interesse dos membros da sociedade a qual pertençam. Desta forma, seria criada uma cadeia de eventos em no qual grupos econômicos que a iniciaram não teriam mais pleno controle. E assim se mostraria a necessidade de "uma intervenção ativa das comunidades culturais no campo das comunicações de massa. O silêncio não é protesto, é cumplicidade; o mesmo ocorrendo com a recusa do compromisso" (ECO, 2006, p. 52).

Douglas Kellner (2001), ao analisar a cultura veiculada pela mídia, seus receptores e a sociedade, vai denominar como cultura da mídia aquela veiculada para população por meio de instrumentos, os quais a indústria cultural utiliza e, mais do que projetar à sociedade os modelos identitários padrões, a mídia se tornaria um espaço de disputa entre ideais reacionários e progressistas, observando que, como produto, necessariamente a cultura precisa da recepção e da aceitação do seu público para a perpetuação de sua produção. Assim, por mais que existissem mecanismos de controle na transmissão destes valores, o público poderia:

[...] resistir aos significados e mensagens dominantes, criar sua própria leitura e seu próprio modo de apropriar-se da cultura de massa, usando a sua cultura como recurso para fortalecer-se e inventar significados, identidade e forma de vida próprios [...] a própria mídia dá recursos que os indivíduos podem atacar ou rejeitar na formação de sua identidade em oposição aos modelos dominantes. (KELLNER, 2001, p. 11).

Mesmo expondo o caráter elitista que a escola de Frankfurt tem ante ao sistema de produção cultural e seu acesso pela população, Kellner (2001) indica os pontos positivos que os estudos trouxeram ao debate como sendo os primeiros a detectarem a importância da indústria cultural. Kellner também estudou o modo como a cultura se mostrava presente na nossa sociedade, tanto em momentos de lazer quanto em um meio de dominação, assim, quando reafirmam ideologias que perpetuam formas de opressão. $O$ autor também expôs como estavam errados os métodos: 
RODRIGUES, Danilo Pontes. Doutrina Bush e violência em In the Shadow of no Towers de Art Spiegelman. Domínios da imagem, v. 13, n. 24, p. 122-156, jan./jun. 2019.

[...] quantitativos para estabelecer relações qualitativas e produziu métodos de análise das complexas relações entre textos, públicos e contextos, bem como do relacionamento entre as indústrias da mídia, o Estado e as economias capitalistas. Portanto, o estudo da comunicação e da cultura foi integrado na teoria da sociedade contemporânea, uma vez que a cultura e a comunicação estavam desempenhando papel cada vez mais significativos. (KELLNER, 2001, p. 47).

Destarte, os estudos de Adorno e Horkheimer se mostram frágeis na formulação de práticas de oposição e resistência de estruturas hegemônicas porque evitaram a política concreta, limitando a objeção a pessoas críticas, não abordando grupos, movimentos ou práticas sociais de divergência.

Por sua vez, os estudos culturais britânicos ${ }^{8}$, partindo do modelo gramsciano, procuram identificar na sociedade formas sociais e culturais hegemônicas de dominação e forças contra-hegemônicas de resistência e, através da dominação e resistência, colaboram com processo de disputa política (KELLNER, 2001). O problema de tais abordagens, como aponta Kellner, são de ao estudarem o que eles denominam de cultura popular, eles vão deixar de fora da sua análise a dita cultura superior (KELLNER, 2001).

Assim, Douglas Kellner vai criticar o termo "cultura de massas" apontando se tratar de um termo elitista, uma vez que cria uma diferenciação binária entre culturas alta e baixa (KELLNER, 2001, p. 50). Neste sentido, o termo cultura popular levantaria uma percepção controversa também, uma vez que passaria a ideia de toda a cultura surgir do povo e é destinada ao povo, não distinguindo da cultura feita para as massas e veiculada pelas mídias (KELLNER, 2001, p. 21). Já a expressão:

\footnotetext{
8 Os estudos culturais britânicos, como ficaram conhecidos, surgiram em 1964 no Birmingham Centre for Contemporary Cultural Studies, e buscavam apresentar uma abordagem cultural a partir de multidisciplinaridade e perspectivas críticas.
} 
RODRIGUES, Danilo Pontes. Doutrina Bush e violência em In the Shadow of no Towers de Art Spiegelman. Domínios da imagem, v. 13, n. 24, p. 122-156, jan./jun. 2019.

[...] "cultura da mídia" também tem a vantagem de dizer que a nossa é uma cultura da mídia, que a mídia colonizou a cultura, que ela constitui o principal veículo de distribuição e disseminação da cultura, que os meios de comunicação de massa suplantaram os modos anteriores de cultura como o livro ou a palavra falada, que vivemos num mundo no qual a mídia domina o lazer e a cultura. Ela é, portanto, a forma dominante e o lugar da cultura nas sociedades contemporâneas (KELLNER, 2001, p. 54).

Considerando as HQs são um produto entre a sociedade que o produz, e a que o recebe, assim o conceito de representação de Roger Chartier nos é relevante, uma vez que, mesmo sabendo que HQs são elementos midiáticos distintos aos livros, mas:

As representações do mundo social assim construídas, embora aspirem a universalidade de um diagnostico fundado na razão, são sempre determinadas pelos interesses de grupo que as forjam. Daí, para cada caso, o necessário relacionamento dos discursos proferidos com a posição de quem os utiliza. As percepções do social não são de forma alguma discursos neutros: produzem estratégias e práticas (sociais, escolares, políticas) que tendem a impor uma autoridade à custa de outros, por elas menosprezados, a legitimar um projeto reformador ou a justificar, para os próprios indivíduos, as suas escolhas e condutas. (adaptado de CHARTIER, 1990, p.17).

Assim entendemos que a mídia exerce uma relação de mão dupla com o seu público, e não apenas no aspecto alienante, tão qual foi sugerido pelos pensadores da escola de Frankfurt.

Como recorte metodológico optamos em fazer a análise do contexto de produção, apontando as ideias vigentes na época, em especial o governo vigente e foi criticado por Art Spiegelman, por meio de uma discussão bibliográfica sobre o assunto. Para a análise dos elementos formais da $\mathrm{HQ}, \mathrm{ou}$ seja, os enquadramentos e elementos gráficos, optamos por seguir a metodologia que Umberto Eco desenvolveu em Apocalipticos e integrados (2006) da HQ Steve Canyon do quadrinista Milton Caniff, análise em que Eco: 
RODRIGUES, Danilo Pontes. Doutrina Bush e violência em In the Shadow of no Towers de Art Spiegelman. Domínios da imagem, v. 13, n. 24, p. 122-156, jan./jun. 2019.

Individuamos [...] os elementos de uma iconografia que, mesmo quando nos reporta a estereótipos já realizados em outros ambientes (o cinema, por exemplo), usa de instrumentos gráficos próprios do "gênero" (ECO, 2006, p. 144).

Isto posto, por meio dos elementos gráficas presentes nas HQs é possível uma compreensão melhor das estratégias apresentadas pelo autor ao elaborar o seu trabalho. Considerando que Spiegelman teve uma autonomia maior na elaboração de In the shadow of no towers, como ele mesmo explicita na introdução da $H Q$, podemos inferir a ausência de intervenção mais contundente de editores.

Portanto, tendo em vista que as imagens da HQ não só fazem parte da própria estrutura narrativa construída pelo autor, mas também são elementos constitutivos centrais da representação elaborada na obra pelo autor, nossa análise dos elementos discursivos da $H Q$, partindo da concepção apresentada por Foucault:

[...] uma tarefa inteiramente diferente, que consiste em não mais tratar os discursos como conjuntos de signos (elementos significantes que remetem a conteúdos ou a representações), mas como práticas que formam sistematicamente os objetos de que falam. Certamente os discursos são feitos de signos; mas o que fazem é mais que utilizar esses signos para designar coisas. É esse mais que os torna irredutíveis à língua e ao ato da fala. É esse "mais" que é preciso fazer aparecer e que é preciso descrever (FOUCAULT, 2008, p. 55).

\section{Guerra e Terror}

Mais do que um ataque dentro do território nacional estadunidense, somando cerca de três mil vítimas, o atentado terrorista foi uma operação planejada e executada com ataques simultâneos, no atentado quatro aviões foram sequestrados, o primeiro atingiu a torre sul do World Trade Center ${ }^{9}$, o segundo atingiu a torre norte do mesmo complexo comercial, o terceiro, o

\footnotetext{
9 Complexo comercial e financeiro situado na região conhecida por baixa Manhattan, sua estrutura contava com sete prédios, um restaurante e um hotel faziam parte do centro.
} 
RODRIGUES, Danilo Pontes. Doutrina Bush e violência em In the Shadow of no Towers de Art Spiegelman. Domínios da imagem, v. 13, n. 24, p. 122-156, jan./jun. 2019.

pentágono ${ }^{10}$ e o quarto caiu em campo aberto na Pensilvânia, seu destino era o capitólio'1 - porém, como fora comprovado posteriormente, os passageiros tentaram retomar controle da aeronave, causando a queda. A Al-Qaeda e seu líder Osama Bin Laden foram apontados como os responsáveis pelos ataques do 11 de setembro, e assim passaram a pertencer ao grupo dos criminosos mais procurados do mundo.

Longe de terem inventado o terrorismo, com a suas ações, o termo entra em voga, assim como o debate sobre o assunto e o medo de novos ataques, se torna generalizado no mundo ocidental de uma forma geral, mas mais especificamente dentro dos Estados Unidos.

Além dos ataques do dia 11 de setembro, houve uma série de ataques de antraz, enviados pelos serviços postais estadunidenses, assombrando a população dos Estados Unidos. O medo era generalizado e a ânsia por capturar os responsáveis ou de se encontrar algum responsável era tremenda.

Assim, não definiremos o termo "terrorismo", mas apresentaremos uma problematização desse termo. A escolha se pauta pelo fato de não existir uma definição única para o tal e, sua concepção se alterar com o passar do tempo ou dependendo da sociedade que o utiliza.

A violência exacerbada se intensificou durante o século XX possui um fator preponderante a ser trazido à discussão: a convicção ideológica de que a causa defendida é tão justa ou o adversário é tão terrível e para se obter a vitória todos os meios são não só válidos, mas se fazem necessários. Tal pensamento poderia justificar as atrocidades cometidas nas duas guerras mundiais (HOBSBAWM, 2007, p. 127).

Sobre terrorismo no século XX, Hobsbawm disse:

10 Construção sede do departamento de defesa dos Estados Unidos.

11 Construção sede do congresso estadunidense, onde ocorrem as reuniões do senado e da câmara dos representantes. 
RODRIGUES, Danilo Pontes. Doutrina Bush e violência em In the Shadow of no Towers de Art Spiegelman. Domínios da imagem, v. 13, n. 24, p. 122-156, jan./jun. 2019.

[...] houve três grandes episódios ou surtos de violência ou contra violência política desde a década de 1960. O primeiro foi um renascer do que se pode chamar apropriadamente de "neoblanquismo", nas décadas de 1960 e 1970, que consistiu em tentativas por parte de certos grupos de elite, em geral pequenos e autoproclamados, empenhados em derrubar regimes ou em alcançar objetivos nacionalistas-separatistas por meio da ação armada [...] O segundo, que só tomou forma já pelo final da década de 1980 e expandiu-se enormemente com as agitações civis e o colapso dos Estados na década de 1990, é principalmente étnico e religioso [...] Nesse período surgiu uma importante inovação que se mostrou singularmente terrível: o homem-bomba [...] Na terceira fase, que parece predominar no início do século atual, a violência política tornou-se sistematicamente global, seja por causa das políticas adotadas pelos Estados Unidos no governo do presidente George W. Bush, seja pelo estabelecimento, talvez pela primeira vez desde $O$ anarquismo do fim do século XIX, de um movimento terrorista que opera conscientemente de maneira transnacional (HOBSBAWM, 2007, p. 129-132).

Desta forma, o caráter do terrorismo altera-se de acordo com o contexto histórico de seus praticantes. Nos casos mais recentes, como os da Al-Qaeda, o fato de serem praticados em um período de alta globalização potencializa o impacto dos ataques na sociedade, já que não se trata de um inimigo específico; assim qualquer pessoa poderia ser o autor do próximo atentado, criando assim um inimigo invisível. Os pilotos que tomaram conta dos aviões e promoveram os ataques estavam em território estadunidense a tempo suficiente para fazerem curso de aviação e aprenderem como pilotar os instrumentos utilizados para a destruição.

Mas, afinal, qual terrorismo é este combatidos e perseguidos pelos Estados Unidos ao ponto de declararem uma Global War on Terrorism? 12 Segundo o U.S. Code:

12 Tradução livre: Guerra Global ao Terrorismo. 
RODRIGUES, Danilo Pontes. Doutrina Bush e violência em In the Shadow of no Towers de Art Spiegelman. Domínios da imagem, v. 13, n. 24, p. 122-156, jan./jun. 2019.

(Um) ato de terrorismo quer dizer qualquer atividade que a) envolva um ato violento ou uma séria ameaça à vida humana que seja considerado delito pelos Estados Unidos ou qualquer outro Estados, ou que seja delito assim reconhecido, se praticado dentro do território jurisdicional americano ou de qualquer outro Estado; e b) aparente (i) ser uma intimidação ou coerção à população civil; (ii) influencie a política governamental por meio de intimidação ou coerção; ou (iii) ameace a conduta de um governo por um assassinato ou seqüestro (United States Code Congressional And Administrative News. $98^{\circ}$. Congresso, Segunda Sessão, 19 de outubro de 1984, volume 2, parágrafo 3077 apud CHOMSKY, 2002, p. 17).

Partindo da definição do próprio código americano, Noam Chomsky apontou que os Estados Unidos seriam um dos maiores terroristas. Para fundamentar o seu argumento, o autor elenca casos como as bombas atômicas de Hiroshima e Nagasaki, além das intervenções militares na Nicarágua, sendo o caso mais emblemático das intervenções militares estadunidenses, uma vez que a Nicarágua recorreu à Corte Mundial, esta deliberou em seu favor, ordenando aos Estados Unidos o fim da intervenção, além do pagamento de indenização (CHOMSKY, 2002, p. 26-27).

Também refletindo sobre o terrorismo praticado pelo governo estadunidense, Domenico Losurdo (2010, p. 25-26) questionou se os planos de assassinatos a Fidel Castro pela CIA, ou mesmo o embargo exercido ao Iraque na década de 1990, durante a guerra do Golfo, que resultou na morte de milhares de pessoas por fome ou doenças, não seriam também práticas terroristas.

Segundo Francis Fukuyama (2006), antes das eleições de 2000 uma agenda para a política externa estadunidense, abarcando intervenção no regime político iraquiano, por meio do que ficou conhecido como hegemonia benevolente, além de relações unilaterais por parte do governo dos Estados Unidos. Tais preceitos, somados às medidas da administração Bush, podem ser observados nos discursos dos integrantes e nos documentos desta administração. 
RODRIGUES, Danilo Pontes. Doutrina Bush e violência em In the Shadow of no Towers de Art Spiegelman. Domínios da imagem, v. 13, n. 24, p. 122-156, jan./jun. 2019.

O autor também indica que preceitos do neoconservadorismo estão imbricados à diversos costumes estadunidenses, podendo ser tomado por "um conjunto coerente de idéias, argumentos e conclusões oriundos da experiência, que devem ser julgados com base na identidade étnica ou religiosa daqueles que adotam esta idéia" (FUKUYAMA, 2006, p. 25). Então, tais ideias do neoconservadorismo podem ser expressados em diversos âmbitos sociais, inclusive na política externa.

Nessa perspectiva, Fukuyama (2006, p. 56-57) aponta ser possível obter quatro aspectos básicos que configuram as ideias neoconservadoras: a crença de que o caráter interno do regime tem importância e que a política externa deve refletir os valores das sociedades liberais democráticas; a crença de que o poder americano pode ser utilizado com finalidades morais, inclusive nos assuntos internacionais; a desconfiança em relação a projetos ambiciosos de engenharia social; e, o ceticismo com relação à eficácia da normatização internacional como promotora da segurança e da justiça.

Ou seja, para o pensamento neoconservador, o modo de se pensar e se fazer política expressa não um pragmatismo, mas um moralismo que se reflete nos valores de democracia e liberdade construídos pelos Estados unidos, crendo se tratar do melhor modelo a ser praticado.

Mesmo apontando as contradições nas medidas do governo norteamericano ao querer combater o terrorismo, considerando o seu currículo, os autores esclarecem que os ataques terroristas de $2001 \mathrm{em}$ momento algum são justificáveis, uma vez que a morte de três mil inocentes nunca seria justificável.

Sobre os atentados, Rubens Ricupero apontou que: 
RODRIGUES, Danilo Pontes. Doutrina Bush e violência em In the Shadow of no Towers de Art Spiegelman. Domínios da imagem, v. 13, n. 24, p. 122-156, jan./jun. 2019.

Um outro tipo de inocência iria, porém, nasce dos atentados contra Nova York e Washington, assim como da devastadora reação norte-americana contra o Afeganistão e o Iraque: a tese superficial do novo Império Romano, a idéia ingênua de que o poderio militar dos Estados Unidos, somado a seus recursos econômicos, Ihes permitiriam fazer o que bem entendessem, inclusive dando plausibilidade a projetos bizarros como o de recriar o Iraque e o mundo árabe inteiro à imagem e semelhança do modelo ianque (RICUPERO, 2003, p. 13).

Com os eventos do 11 de Setembro, muito se especula quanto aos atentados, cria-se a necessidade de respostas urgentes, já que parte da sociedade estadunidense não compreende os motivos dos ataques terroristas. Para pensar tais eventos e suas reações por parte da população estadunidense, é necessário ter em vista que o alcance global da propagação das imagens da destruição das torres gêmeas só foi possível graças à presença instituída dos meios de comunicação de massa em tal contexto.

Pensando a relevância dos acontecimentos dentro das pesquisas históricas, François Dosse revelou que:

[...] as mass media participam plenamente da própria natureza dos acontecimentos que elas transmitem. Cada vez mais, é através delas que o acontecimento existe. Para ser, o acontecimento deve ser conhecido, e as mídias são de maneira crescente os vetores dessa tomada de consciência [...] Com a mídia televisiva, essa centralidade na fabricação do acontecimento não parou de crescer. As imagens dos primeiros passos do homem na Lua construíram o momento de um acontecimento mundial graças à televisão que o retransmitiu ao vivo. A tragédia do dia 11 de 11 de 2001, que se inclui ainda no qualificativo de "acontecimento-monstro", na sua acepção dramática, é igualmente um acontecimento-mundo (DOSSE, 2013, p. 260-261).

Houve a veiculação das imagens dos aviões atingindo as torres em tempo real, em praticamente todo o mundo, o que causou um impacto diferente em toda sociedade, uma vez que não se tratavam de imagens com edições. Assim, o espectador testemunhou o acontecimento praticamente na íntegra. 
RODRIGUES, Danilo Pontes. Doutrina Bush e violência em In the Shadow of no Towers de Art Spiegelman. Domínios da imagem, v. 13, n. 24, p. 122-156, jan./jun. 2019.

Desta forma, o sistema informativo apresenta um caráter paradoxal: ele, que apresenta a característica de reduzir as incertezas, trazendo indicações para o seu receptor, também bombardeia o seu público com um conhecimento enigmático, sem significações, e espera dele o seu sentido. Há assim, na sociedade midiatizada, uma "inflação acontecimental", que tem um duplo efeito: o de facilitar a ampla ciência do acontecimento, porque ocorre a aceleração da transmissão das informações e, em contrapartida, torna a interpretação e a definição de um sentido para estes acontecimentos mais difíceis, justamente pela quantidade excessiva de dados apresentadas. Nesse sentido, o acontecimento seria detentor de um aspecto enigmático, de "esfinge", já que ele sempre apresenta problemas questionadores a todos os sistemas de explicação, sem, contudo, encontrar a resposta satisfatória (DOSSE, 2013, p. 262-264).

É dentro dessa ânsia de se achar um sentido para o 11 de setembro que as teorias da conspiração ${ }^{13}$ sobre os atentados ganham mais força, tais teorias poderiam ser criadas mesmo fora do contexto apresentado; contudo, é a sua visibilidade e repercussão que são incentivadas devido ao caráter único dos ataques.

No ano de 2006, Lawrence Wright publica seu trabalho jornalístico intitulado O vulto das torres - a Al-Qaeda e o caminho até o 11/9, na obra, o autor buscou traçar um histórico da organização desde a sua influência com o poeta egípcio, Sayyid Qutb, até os eventos do 11 de setembro. Mesmo que - autor faça uma pesquisa documental e bibliográfica bastante rica, em alguns momentos, fica refém de entrevistas com membros da Al-Qaeda e membros do FBl14, fontes que podem querer esconder algumas informações, apresentar falsos depoimentos ou depoimentos tentando induzir outras interpretações. Fato que o autor tem consciência e, embora ele mesmo

\footnotetext{
13 Pode-se observar cinco dessas teorias no site da BBC (BBC, 2011).

${ }^{14}$ Agência federal de investigação americana.
} 
RODRIGUES, Danilo Pontes. Doutrina Bush e violência em In the Shadow of no Towers de Art Spiegelman. Domínios da imagem, v. 13, n. 24, p. 122-156, jan./jun. 2019.

reserve uma reflexão crítica sobre o assunto, fica restrito a um espaço curto após as notas e a bibliografia.

Assim, o autor aponta a existência de sinais suficientes para se ampliar uma investigação em cima dos membros da Al-Qaeda que estavam tendo aulas de pilotagem de avião. Contudo, a burocracia institucional, ou mesmo a descrença por parte dos funcionários do FBI levaram a não averiguação destes indícios (WRIGHT, 2007, p. 384-385). Esta mesma pesquisa apresenta um relato de um membro da Al-Qaeda em que este conta ter pensado que a explosão dos tanques geraria calor suficiente a ponto de fazer a estrutura de aço perder suas propriedades e então desabar (WRIGHT, 2007, p. 404-405). Quanto ao financiamento da organização, seus ataques no fim do século XX serviram como um chamariz para novos doadores interessados em contribuir com as ações do grupo, tais doadores seriam simpatizantes, do conceito de Jihad ${ }^{15}$ pregado pela Al-Qaeda (WRIGHT, 2007, p. 328-331).

Portanto, o terrorismo entra em grande evidência devido aos ataques promovidos pela Al-Qaeda e a mudança do caráter do terrorismo deixa de ser um fenômeno político, étnico e religioso e passa a ser global. Mesmo tendo retórica de combate a este tipo de ação, os Estados Unidos acabaram demonstrando mais medidas coercitivas, unilaterais e apressadas do que soluções significativas para os atentados, como foram as guerras do Afeganistão e do Iraque.

Mais do que ser uma grande tragédia do início do século XXI, os atentados terroristas nos Estados Unidos inauguram uma nova forma de terrorismo com ações globais, em que seus autores são anônimos e qualquer um pode ser seu aliado ou membro de alguma organização.

Após a ascensão dos regimes fascista e nazista no início do século XX, o interesse acadêmico pelos regimes autoritários se voltou para este assunto. Evidentemente, não podemos classificar o governo estadunidense como

\footnotetext{
15 Também conhecida como guerra santa, é um conceito muçulmano que representa "empenho" ou "luta" onde os muçulmanos enfrentariam os seus "inimigos" a fim de atingir a fé perfeita.
} 
RODRIGUES, Danilo Pontes. Doutrina Bush e violência em In the Shadow of no Towers de Art Spiegelman. Domínios da imagem, v. 13, n. 24, p. 122-156, jan./jun. 2019.

sendo um regime autoritário em seus aspectos mais amplos, uma vez que as instituições democráticas continuaram e continuam desempenhando o seu papel, mesmo após os atentados. Analisando os aspectos psicossociais do autoritarismo, além de fazerem um balanço dos autores que trabalham com os conceitos de autoritarismo, Thaís Santiago Barros, Ana Raquel Rosas Torres e Cícero Pereira indicam que:

[...] as pessoas que valorizam a conformidade têm também uma visão muito pessimista da natureza humana, que traz em sua essência a ideia de que os indivíduos precisam de normas rígidas para conviver em sociedade, caso contrário, cairiam na barbárie. Eles também defendem punições rígidas para aqueles que se desviaram das normas sociais, sendo inclusive a favor de limitar a liberdade e os direitos civis. Por outro lado [...] aquelas pessoas que valorizam a autonomia pessoal mais do que a conformidade social também acreditam na habilidade das pessoas de interagir em liberdade e com autonomia e ainda assim viverem uma estabilidade social. (BARROS; TORRES; PEREIRA, 2009, p. 49).

É dentro de tal perspectiva que entendemos o governo Bush exerceu medidas autoritárias, sejam elas com a justificativa de se punir os responsáveis pelos atentados, ou para evitar novos atentados. Ante a isso, algumas perguntas se fazem necessárias: Como se constituíram tais processos? Como tais medidas foram criticadas ou interpretadas? Como Spiegelman vai abordar e expressar suas impressões sobre tais questões? Perguntas estas que buscaremos responder.

Com os atentados, foi reconhecido que o sistema de segurança americano sofreu um forte abalo. Contudo, os Estados Unidos e a sua democracia iriam superar aquele momento difícil. Não se renderiam às ações terroristas e, mais, prometeu encontrar os responsáveis pelos atentados, assim como os seus colaboradores e iriam tratar de puni-los, por meio do que ficou conhecido como Global War on Terrorism 16, ou GWT.

16 Tradução livre: Guerra Global contra o Terrorismo. 
RODRIGUES, Danilo Pontes. Doutrina Bush e violência em In the Shadow of no Towers de Art Spiegelman. Domínios da imagem, v. 13, n. 24, p. 122-156, jan./jun. 2019.

Os Estados Unidos, antes da declaração de guerra, tinham exigido ao Afeganistão que entregasse Osama Bin Laden, o país afegão recusou-se, e chamou a atenção internacional para o assunto, que foi considerado, pelos Estados Unidos, como uma medida desesperada em busca de apoio do mundo muçulmano (CHOMSKY, 2002, p. 87). Mas, se em 2001, o governo Talibã no Afeganistão e Osama Bin Laden são apontados como inimigos, devido aos atentados terroristas e à falta de colaboração para a captura dos criminosos, respectivamente; apesar de na década de 1980, mais especifico em seu fim, no período conhecido como fim do período conhecido como fim da guerra fria, as relações dos Estados Unidos com ambos se deu de forma distinta do que se configurou no início do século XXI:

[...] a tomada do Afeganistão pela União Soviética no mesmo ano. A CIA lançou a maior guerra secreta da história no Afeganistão, recrutando fundamentalistas islâmicos para lutar contra a União Soviética. O apoio dado aos grupos Al-Qaeda e Talibã, que conseguiram ao final vencer os soviéticos e estabelecer um regime religioso antidemocrático, mais tarde assombraria os Estados Unidos (PURDY, 2008, p. 262).

Portanto, mais do que estarem auxiliando os terroristas, na visão americana, o Afeganistão se recusou a atender as suas exigências.

Contudo, a guerra contra o Afeganistão poderia ser compreendida como um empreendimento militar rápido, sem grandes baixas e como uma resposta para as críticas presentes à campanha militar. Característica bélica que Slavoj Žižek vai entender dentro de um contexto virtual: 
RODRIGUES, Danilo Pontes. Doutrina Bush e violência em In the Shadow of no Towers de Art Spiegelman. Domínios da imagem, v. 13, n. 24, p. 122-156, jan./jun. 2019.

Hoje encontramos no mercado uma série de produtos desprovidos de suas propriedade malignas: café sem cafeína, creme de leite sem gordura, cerveja sem álcool... E a lista não tem fim: que dizer do sexo virtual, o sexo sem sexo; da doutrina de Colin Powell da guerra sem baixas (do nosso lado, é claro), uma guerra sem guerra; da redefinição contemporânea da política como arte da administração competente, ou seja, a política sem política; ou mesmo o multiculturalismo tolerante de nossos dias, a experiência do Outro sem sua Alteridade lo Outro idealizado que tem danças fascinantes e uma abordagem holística ecologicamente sadia da realidade, enquanto práticas como o espancamento das mulheres ficam ocultas...)? A realidade Virtual simplesmente generaliza esse processo de oferecer um produto esvaziado de sua substância, do núcleo duro e resistente do Real-assim como o café descafeinado tem um aroma e o gosto do café de verdade sem ser o café de verdade, a Realidade Virtual é sentida como a realidade sem o ser (ŽlŽEK, 2003, p. 24-25).

Ademais, embora se tenha a tecnologia dos veículos aéreos não tripulados desde 1959, que foram utilizados no serviço de espionagem durante a Guerra Fria e o início de suas experiências com armamentos em 1994, os Estados Unidos dizem que começaram a utilizar drones armados em guerras somente a partir da invasão ao Afeganistão em 2001.17

17 Como pode ser verificado em Terra (2013). 
RODRIGUES, Danilo Pontes. Doutrina Bush e violência em In the Shadow of no Towers de Art Spiegelman. Domínios da imagem, v. 13, n. 24, p. 122-156, jan./jun. 2019.

Imagem 2 - Equally terrorized by Al-Qaeda and by his own government..., excerto da prancha número 2.

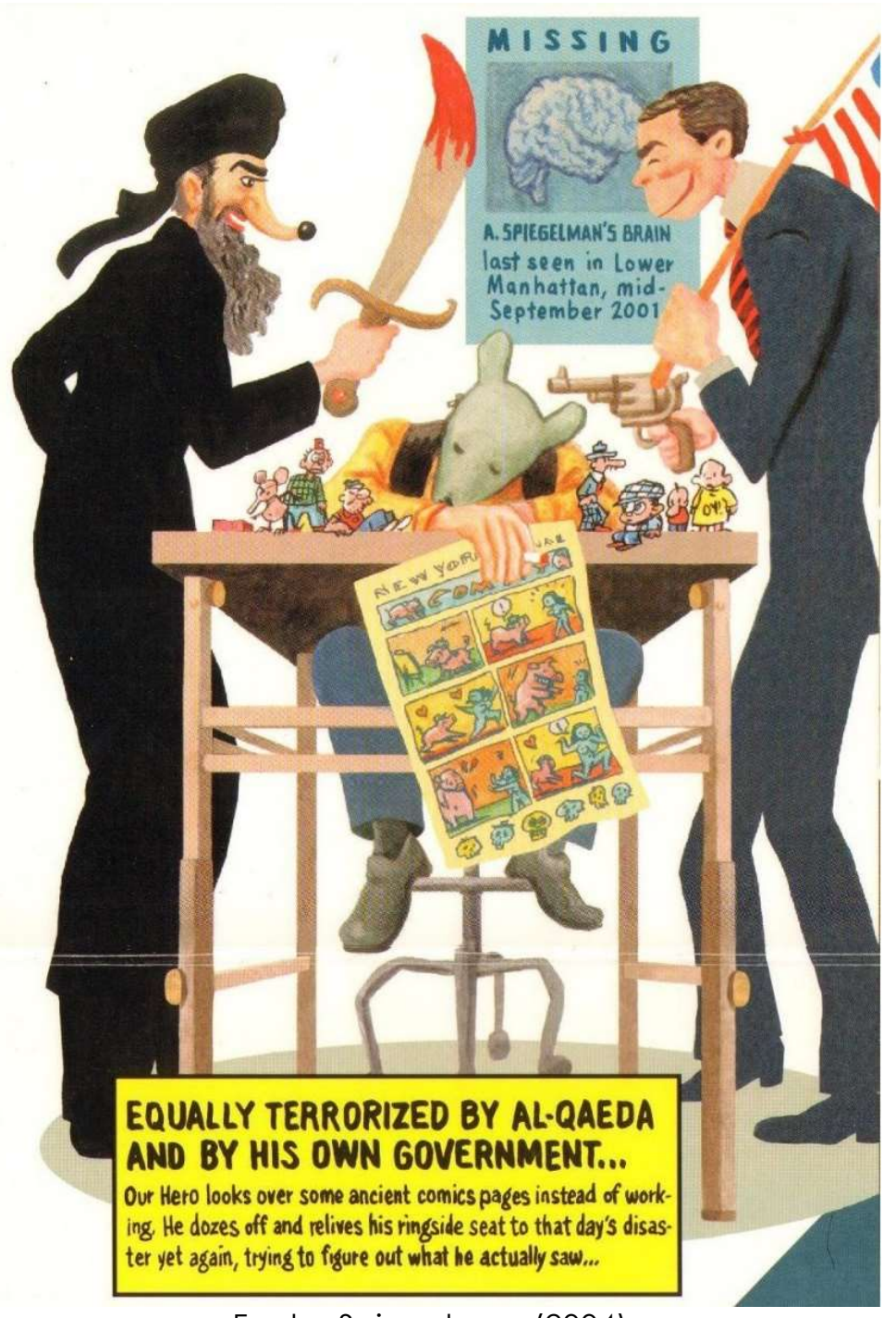

Fonte: Spiegelman (2004).

Como resultado da intervenção militar no país, os talibãs foram depostos, houve a indicação de um chefe de estado provisório em 2002. Já, em 2004, o Afeganistão ganharia uma nova constituição e elegeria o Presidente Karzai; posteriormente, em 2005, ocorreriam eleições parlamentares, de acordo com a nova constituição do país. Contudo, isso não foi o suficiente para sanar os conflitos internos e diversas manifestações relevantes contra o novo regime imposto pelo Ocidente, isso porque esse 
RODRIGUES, Danilo Pontes. Doutrina Bush e violência em In the Shadow of no Towers de Art Spiegelman. Domínios da imagem, v. 13, n. 24, p. 122-156, jan./jun. 2019.

cenário não era bem visto por parte da população. A guerra tampouco cessou a produção de ópio e o narcotráfico, real alimento das reservas financeiras do talibã, além de ter incentivado a população a ir contra o exército invasor.

Spiegelman, na Imagem 2, se representa e nas duas extremidades da mesa de desenhos, são retratados de um lado, Osama Bin Laden e, de outro, George W. Bush, ambos se encarando. O primeiro segura em suas mãos uma cimitarra ensanguentada, já o segundo uma bandeira dos Estados Unidos e um revólver. Ambos são retratados em posição equivalente, ressaltando a ideia de terem a mesma capacidade de aterrorizar ao autor. Considerando que muito se acusou o islamismo de extremo ódio ao Ocidente, Domenico Losurdo argumentou que:

Afinal, há um islã moderado: É pena que raramente essa
pergunta legítima seja completada por outra, igualmente
legítima: há um Ocidente moderado, ou não dogmático, capaz
de colocar-se a si mesmo em discussão e de compreender as
razões dos outros? [...] Mas os movimentos empenhados em
conquistar uma real independência e dignidade nacionais e
que, para tal fim, aspiram às vezes, a construir uma União Árabe
segundo modelo da União europeia demonstram que
souberam aprender com o ocidente. É uma lição que, uma vez
aprendida, não se desaprende mais, apresar de todos os
esforços do Ocidente mais extremista e dogmático. Quando,
em nome da difusão universal da democracia como
fundamento estável da paz, pretende ditar lei no Oriente Médio
e em todo o mundo, passando por cima de soberanias,
dignidades e sensibilidades nacionais, Bush Jr. argumenta do
mesmo modo de Bin Laden: limita-se a definir de maneira
diferente a "casa da paz", que não é mais representada pelo
islã, mas pelo conjunto dos países mais estreitamente ligados a
Washington (LOSURDO, 2010, p. 273-274).

Se constantemente e de forma arbitrária os muçulmanos são generalizados como um grupo fundamentalista pronto para enfrentar a guerra santa, os Estados Unidos constroem sua república pautada em discursos religiosos, em que os peregrinos eram pessoas portadoras da palavra de Deus para a região. Ademais, discursos de presidentes trazem a expressão 
RODRIGUES, Danilo Pontes. Doutrina Bush e violência em In the Shadow of no Towers de Art Spiegelman. Domínios da imagem, v. 13, n. 24, p. 122-156, jan./jun. 2019.

"God bless America!"18 como uma invocação ritualística. Considerando a impossibilidade de Deus ser neutro, então opta por estar do lado da nação escolhida por ele para combater e subjugar o mal (LOSURDO, 2010, p. 93).

Percebe-se a particularidade das armas seguradas por cada um. A cimitarra é associada aos povos árabes ou de religião muçulmana, em contraponto, o revólver com tambor giratório,criado por um americano, Samuel Colt. Apesar de ser amplamente debatido e criticado, o direito à comercialização e ao porte de armas de fogo é muito forte na cultura americana, sendo a segunda emenda da constituição do país (KARNAL, 2008, p. 17). E mesmo sendo um país que teve três presidentes assassinados por armas de fogo e nove sofreram tentativas de assassinato ${ }^{19}$, a defesa da manutenção do direito ao porte de armas é muito presente nos Estados Unidos.

A guerra contra o Afeganistão se consolida com o argumento da vingança e a busca pela justiça ante aos atentados do 11 de setembro, uma guerra necessária para a manutenção do governo estadunidense em uma demonstração de soberania e reação. Em contrapartida, a guerra contra o Iraque possui motivos distintos e duvidosos, tanto que não chegaram a conseguir apoio da ONU, como também países como Alemanha e França, se opuseram prontamente à situação (PECEQUILO, 2012, p. 66-67).

O motivo oficial para a intervenção no Iraque, em março de 2003, era que o país e o seu "monstruoso" governante, Saddam Hussein, possuíam armas de destruição em massa e caracterizavam uma ameaça ao Oriente Médio, afinal, o país tentou dominar a região durante a guerra do golfo nos anos 1990. E, como apontou George W. Bush, em um discurso:

\footnotetext{
18 Tradução livre "Deus abençoe a América!".

19 Os presidentes assassinados foram: Abraham Lincoln, em 1865; William McKinley, em 1901 e John Fritzgerald Kennedy, em 1963; os que sofreram tentativas de assassinato: Andrew Jackson, em 1835; Theodore Roosevelt, em 1912; Franklin Delano Roosevelt, em 1945 e Harry Truman, em 1950. Além deles, Richard Nixon, em 1974, Gerald Ford (1975), Jimmy Carter (1979) e Ronald Reagan em (1981), como pode se verificar em BBC (2011).
} 
RODRIGUES, Danilo Pontes. Doutrina Bush e violência em In the Shadow of no Towers de Art Spiegelman. Domínios da imagem, v. 13, n. 24, p. 122-156, jan./jun. 2019.

O Iraque continua a mostrar a sua hostilidade por toda a América e a apoiar o terror. O regime iraquiano planejou fabricar anthrax, gás de nervos e bombas nucleares para matar milhares dos seus próprios cidadãos - deixando os corpos de mães amontados por cima dos seus filhos mortos. Este é um regime que acordou na existência de inspetores internacionais - e depois deportou-os. Este é um regime que tem algo a esconder do mundo civilizado. (BUSH, 2002a, tradução nossa).

Tais alegações que, após a invasão, captura e morte do ditador iraquiano, são comprovadas como falsas, até porque os governos estadunidense e britânico assumem publicamente o "erro". Contudo o discurso posterior é de que a guerra foi necessária para a queda de um governo ditatorial hostil à região.

Imagem 3 - Excerto da prancha de número 5.
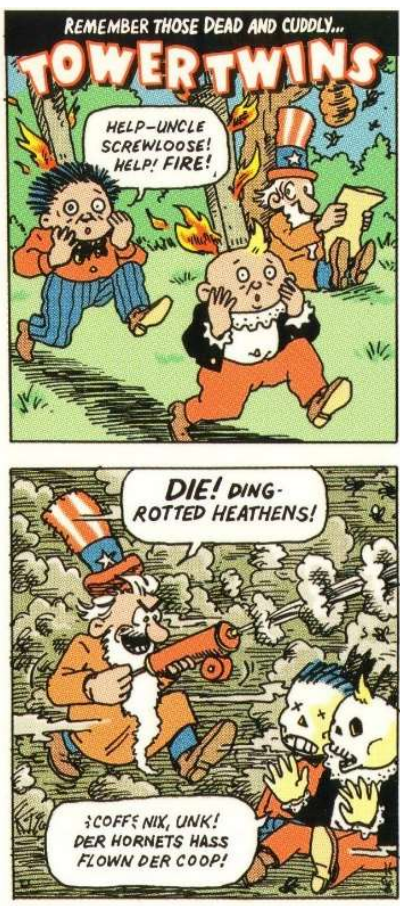
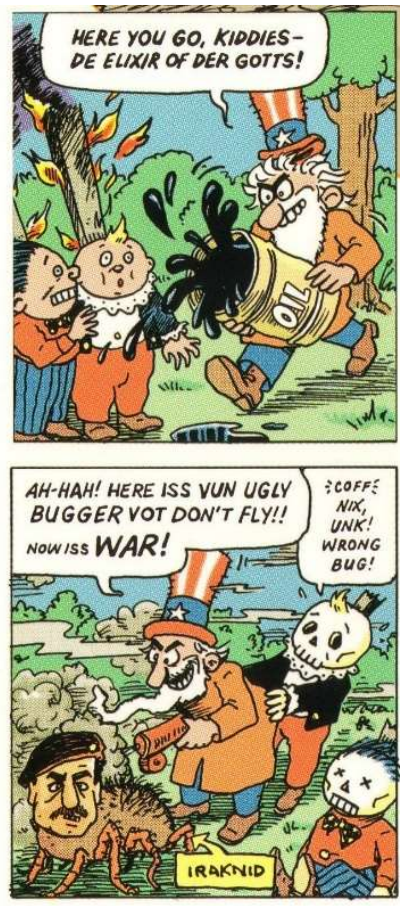
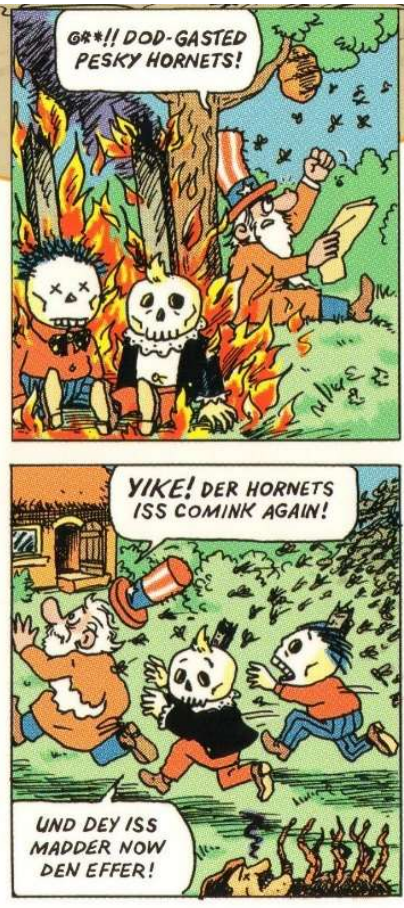
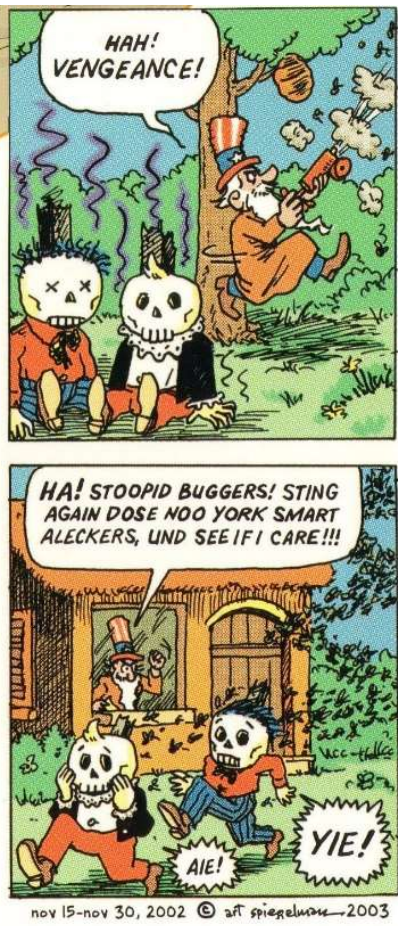

Fonte: Spiegelman (2004).

Assim, a guerra contra o Iraque se configura como uma guerra preventiva, dentro da lógica que os Estados Unidos precisavam atacar o Iraque antes que pudesse causar qualquer dano às populações vizinhas. Tal política foi comparada por Slavoj Žižek (2003, p. 09-10) com o filme Minority 
RODRIGUES, Danilo Pontes. Doutrina Bush e violência em In the Shadow of no Towers de Art Spiegelman. Domínios da imagem, v. 13, n. 24, p. 122-156, jan./jun. 2019.

Report, de 2002, na película os criminosos são presos antes mesmo de cometerem os seus crimes.

O economista Henrique Tomé da Costa-Mata demonstra como o petróleo é fundamental para a questão, sugerindo que a mobilização bélica deu-se devido à decisão do governo iraquiano de exportar petróleo faturando em euro e não em dólar, a partir de 2000. O autor também traz um levantamento da evolução das cotações de ambas as moedas e como isso influenciou o mercado internacional, uma vez que, com a criação do euro, o dólar não possuía um concorrente monetário, foi justamente a queda dos juros praticada pelo governo estadunidense, a fim de se tornar uma moeda mais atrativa ante o seu rival direto que resultou em sua desvalorização (COSTAMATA, 2011, p. 715). Não foi a decisão da moeda para exportação de seu petróleo o único fator para o empreendimento militar contra o Iraque, contudo, este é um ponto a ser considerado.

Pensando a violência empregada pelo governo estadunidense, trechos de In the shadow of no towers são expressivos. Como citado anteriormente, Spiegelman optou por produzir 10 pranchas com HQs aos moldes das HQs do início do século XX, as pranchas não apresentam conexão direta uma com a outra além de utilizar de personagens das tiras clássicas. Os trechos que aparecem os personagens Hanz e Fritz de Os sobrinhos do capitão ou Katzenjammer Kids, em sua HQ original, criada por Rudolph Dirks, expressavam um espírito jovem, sempre aprontando travessuras contra a Mama, o Capitão e o Coronel. Eventualmente eram pegos e sofriam castigos físicos (GOIDANICH; KLEINERT, 2014, p. 130-131).

Na Imagem 4 identificamos os gêmeos representados com as torres em chamas, em três quadros. Em dois deles os meninos estão correndo com semblantes extremamente assustados, enquanto em um terceiro quadro eles aparecem apanhando do capitão. Spiegelman nesta ocasião não retratou o capitão como de praxe nas HQs, utilizando um chapéu ou quepe, mas sim, usando um turbante, simbolizando os terroristas da Al-Qaeda, os quais 
RODRIGUES, Danilo Pontes. Doutrina Bush e violência em In the Shadow of no Towers de Art Spiegelman. Domínios da imagem, v. 13, n. 24, p. 122-156, jan./jun. 2019.

estariam castigando os americanos pelas suas "travessuras". Tudo isso é representado a fim de indicar que os atentados foram uma resposta às ações estadunidenses.

Imagem 4 - Prancha de número 2.
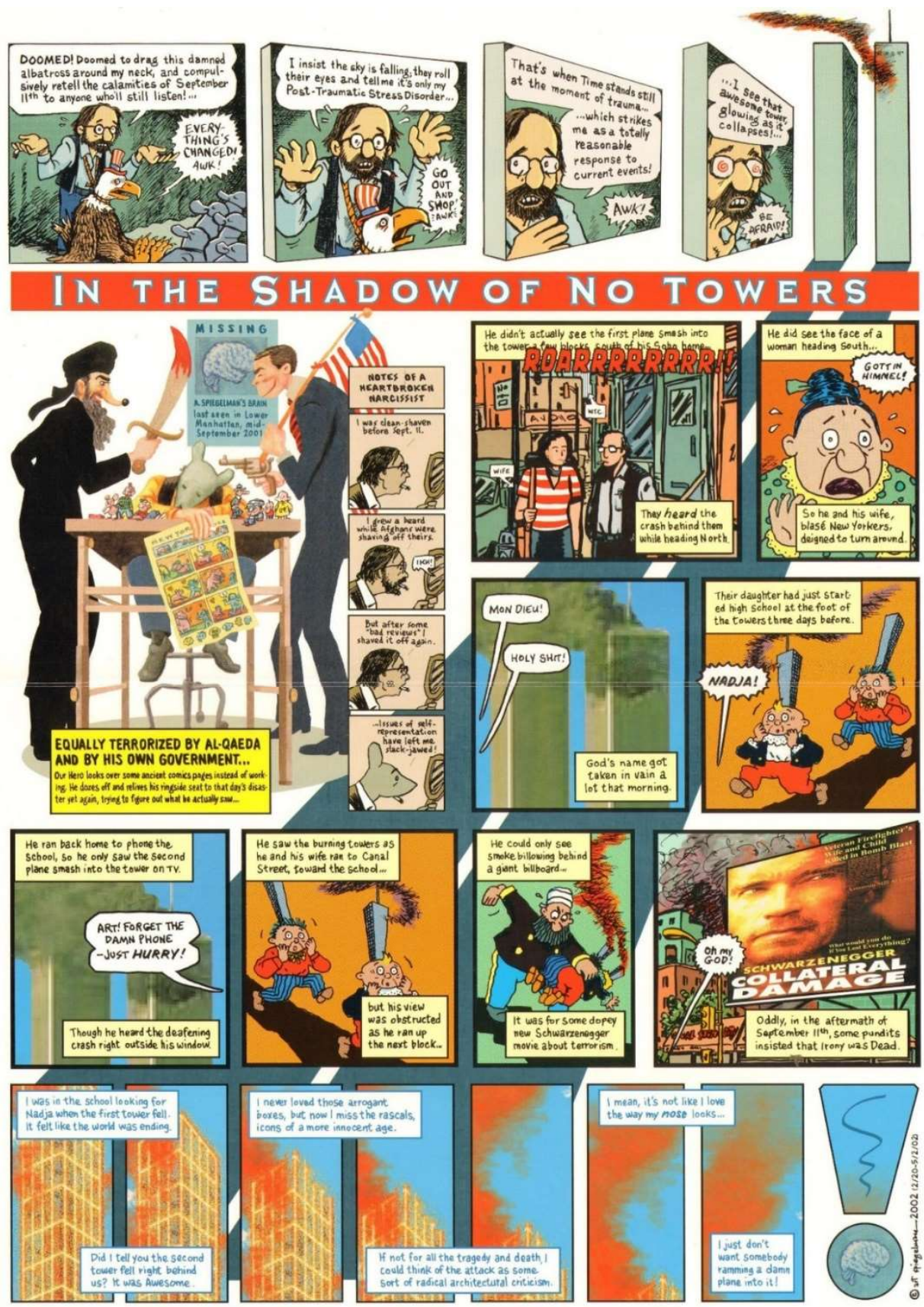

2

Fonte: Spiegelman (2004). 
RODRIGUES, Danilo Pontes. Doutrina Bush e violência em In the Shadow of no Towers de Art Spiegelman. Domínios da imagem, v. 13, n. 24, p. 122-156, jan./jun. 2019.

Pode-se verificar na Imagem 5 a aparência original dos personagens, em situação muito próxima. Os personagens de Rudolph Dirks foram usados em outro momento, como se pode conferir na Imagem 3, que possui a sequência de quadros retrata os "Tower Twins" ou "gêmeos torres", apresentando o mesmo semblante da Imagem 4, pedindo ajuda ao Uncle Screwloose20, uma recriação do Coronel, um inspetor da escola que os gêmeos frequentam e ocasionalmente os pega matando aula para executar suas brincadeiras. Quando isso ocorre, ele se satisfaz em vê-los apanhando, como se pode ver na Imagem 5, uma vez que suas torres estão em chamas.

Uncle Screwloose é caracterizado como uma alusão ao Tio Sam, a personificação do estado nacional dos Estados Unidos e, na Imagem 3, ao invés de ajudar os gêmeos, tenta apagar o fogo com petróleo, agravando o incêndio. Na sequência, o tio começa a ser incomodado por um ataque de vespas e revida jogando inseticida. Tanto o petróleo quanto o inseticida são críticas à guerra contra o Afeganistão e seu objetivo de interferência na região, assim como os empreendimentos militares promovidos pelos Estados Unidos no decorrer do século XX, considerando o petróleo como um dos principais recursos do país e da região.

Quando o tio encontra o "Iraknid", representado com o rosto do então presidente do Iraque, Saddam Hussein, um dos sobrinhos tenta impedi-lo de matá-lo, alegando ser o inseto errado. É uma referência à guerra promovida contra o Iraque, que partiu da alegação de ser ele detentor de armas de destruição em massa, e se mostrou, posteriormente, uma informação falsa. Esta guerra, como foi abordado no capítulo anterior, não teve tanta aceitação quanto à guerra contra o Afeganistão.

Na sequência, ainda na Imagem 3, observam-se as vespas retornando em maior quantidade e mais bravas. Enquanto Uncle Screwloose se abriga em uma casa, as crianças continuam desabrigadas sob ataque das vespas. Uncle Screwloose diz que não se importaria se as crianças de Nova lorque

20 Tio miolo-mole ou parafuso solto (tradução livre). 
RODRIGUES, Danilo Pontes. Doutrina Bush e violência em In the Shadow of no Towers de Art Spiegelman. Domínios da imagem, v. 13, n. 24, p. 122-156, jan./jun. 2019.

fossem picadas novamente. É possível notar os sotaques alemães dos personagens mantidos na fala das personagens, uma vez que nas histórias originais eles viviam em uma colônia alemã.

Então, Spigelman utiliza do aspecto sádico original dos personagens para criticar as medidas do governo estadunidense. No trecho retratado, as vespas simbolizam os terroristas que, com toda a interferência do país no Oriente Médio, acabam se incomodando mais.

Outra leitura possível é que os ataques das vespas representariam o revide dos afegãos e iraquianos contra as tropas estadunidenses invasoras ao seu país. $O$ inseticida representa as medidas contra o terrorismo adotadas pelo governo, obstruindo assim a visão das crianças, representando a dificuldade de se compreender o cenário político e as consequências destas medidas. Já os gêmeos representam a população estadunidense, que fica suscetível a novos atentados graças às medidas do seu governo.

Imagem 5 - Os personagens Hanz e Fritz.

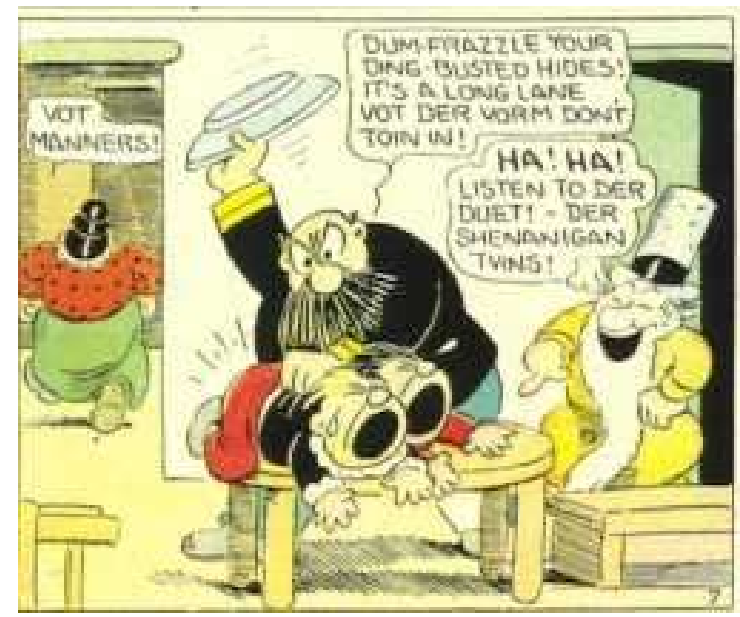

Fonte: Yodaslair (1997).

Ainda, é possível delinear outra leitura no trecho apresentado. Os insetos representariam os combatentes afegãos e iraquianos que, após a invasão de seus países em seus territórios, revidaram as tropas americanas surpreendendo o governo estadunidense, uma vez que estavam lhes fazendo um favor ao invadir seus territórios, matando seus conterrâneos e substituindo seus líderes 
RODRIGUES, Danilo Pontes. Doutrina Bush e violência em In the Shadow of no Towers de Art Spiegelman. Domínios da imagem, v. 13, n. 24, p. 122-156, jan./jun. 2019.

políticos (LOSURDO, 2010, p. 50). Dentro desta ótica, os gêmeos fazem alusão aos soldados americanos que lutam as guerras, entrando em risco de morte enquanto os governantes americanos ficam livres dos perigos das guerras.

\section{Tortura e repercussões}

Assim, houve inclusão do Iraque no chamado "eixo do mal", faziam parte desta classificação países como Venezuela, Irã, Coreia do Norte, Líbia, Síria e Cuba. Segundo demonstra Pecequilo, dentro da doutrina Bush, aqueles que não se alinhavam aos seus interesses eram apontados como inimigos ou aliados a estes (PECEQUILO, 2012, p. 22-23).

Outra interpretação possível acerca das representações dos personagens do Os sobrinhos do capitão é a perseguição a possíveis terroristas, que foi amparado pelas medidas aprovadas pelo Patriot Act, além de outras medidas como:

Em 13 de novembro de 2001 o Presidente Bush, sem consultar o Congresso, assinou uma ordem militar que permitia que os inimigos estrangeiros fossem julgados por juntas militares. Anteriormente, frente a alguns membros da Al-Qaeda suspeitos de terem tomado parte nos atentados contra as embaixadas americanas em Kenya e Tanzania em 1998 (atentados que provocaram a morte de 200 pessoas), se intentou uma ação penal que obteve resultado positivo; os imputados foram julgados por juízes penais comuns nos Estados Unidos. $O$ Presidente, na qualidade de Comandante Supremo das forças armadas, pode decidir que os imputados serão julgados por juntas militares em caso de violações de leis de guerra. Este poder se fundamenta nos artigos I e $\|$ da constituição americana. O problema se restringe em que as guerras se declaram aos países e, neste caso, não houve nenhuma declaração oficial de guerra contra a Al-Qaeda. Além disso, os membros da Al-Qaeda não são cidadãos de um Estado concreto a que se possa aplicar o Enemy Alien Act. Contudo, a Suprema Corte reconheceu que os Estados Unidos podem encontrar-se em estado de guerra sem uma declaração formal de guerra, o que significa que podem instituir-se, de qualquer modo, juntas militares sem maior motivo. (VERVAELE, 2014, p. 52).

Tal decisão, aliada ao Patriot Act, possibilitou a perseguição, captura e interrogatório dos suspeitos de ações terroristas, aspectos que desenvolveremos neste item do trabalho. 
RODRIGUES, Danilo Pontes. Doutrina Bush e violência em In the Shadow of no Towers de Art Spiegelman. Domínios da imagem, v. 13, n. 24, p. 122-156, jan./jun. 2019.

Na invasão ao Iraque, em 2003, houve resistência por parte da população iraquiana, taxada automaticamente como terrorista, os "terríveis cortadores de cabeças", não que tal prática não tenha sido exercida por alguns iraquianos mais fervorosos em combater os americanos, não obstante, Domenico Losurdo vai apontar que práticas terríveis como as citadas acima não foram exclusivas dos iraquianos, expõe relatos de tropas americanas rindo e zombando de corpos iraquianos mortos, além dos abusos ocorridos na prisão de Abu Graib (LOSURDO, 2010, p. 36-37).

Pensando o tratamento que é dado não somente aos prisioneiros de guerra, mas aos suspeitos de terrorismo e também aos combatentes afegãos, Žižek vai repensar o conceito de Homo Sacer:

Ao ser perguntado pelos jornalistas sobre os objetivos dos bombardeios americanos no Afeganistão, Donald Rumsfeld respondeu simplesmente: "Matar o maior número possível de soldados talibãs e membros da Al-Qaeda" [...] O problema da declaração grosseira de Rumsfeld, bem como com outros fenômenos semelhantes, como a condição incerta dos prisioneiros afegãos na Baía de Guantánamo, é o fato de parecerem apontar diretamente para a distinção de Agamben entre o cidadão total e o Homo sacer que, apesar de um ser humano vivo, não é parte da comunidade política [...] quando comete um crime grave, assassinato, por exemplo, um cidadão americano continua sendo um "criminoso legal"; a distinção entre criminosos e não criminosos nada tem em comum com a distinção entre cidadãos "legais" [...] Os excluídos são não apenas os terroristas, mas também os que se colocam na ponta receptora da ajuda humanitária (ruandeses, bósnios, afegãos...): o Homo sacer de hoje é o objeto privilegiado da biopolítica humanitária: o que é privado da humanidade completa por ser sustentado com desprezo (ŽlŽEK, 2003, p. 111).

Haveria então a busca e o objetivo de acabar com a vida dos antagonistas, e não da captura e condenação dos criminosos, este seria o procedimento minimamente legal e humanitário no sentido de se seguir o sistema jurídico e os acordos internacionais, que deveriam regulamentam este tipo de procedimento a fim de primar pelos direitos humanos. Contudo, tratase de uma guerra diferente, em que o oponente é taxado como criminoso mesmo se limitando a defender seu território, isso transforma a noção de quem 
RODRIGUES, Danilo Pontes. Doutrina Bush e violência em In the Shadow of no Towers de Art Spiegelman. Domínios da imagem, v. 13, n. 24, p. 122-156, jan./jun. 2019.

seriam os inimigos terroristas. Assim, é possível categorizar os envolvidos como "combatentes ilegais" e não soldados inimigos, são criminosos apolíticos, e, portanto, seriam desprovidos do espaço político propriamente dito (ŽlžEK, 2003, p. 113).

Isto possibilitará, anos mais tarde, o presidente George W. Bush falar publicamente sobre as técnicas de interrogatório, alegando inclusive a prática de Waterboarding ${ }^{21}$ não sendo um método de tortura uma vez que está dentro das leis americanas, contudo, foram aplicadas somente em três prisioneiros membros da Al-Qaeda e também alegar que os interrogatórios evitaram novos ataques terroristas 22.

Nesse cenário, mais do que transformar os criminosos em indivíduos desprovidos de direitos, os tornaram merecedores da tortura. Assim, mesmo se posicionando contra práticas de tortura, tais procedimentos quando aplicados em suspeitos de terrorismo não só se é justificável para se evitar novos atentados, mas também como uma forma de punição.

Pensando este tipo de ação voltada aos autores de atos terroristas, seus colaboradores e possíveis suspeitos, seriam todas ações consequentes de uma primeira resposta aos ataques terroristas, O USA PATRIOT ACT, oU também conhecido como ato patriota, assinado por George W. Bush no final de outubro de 2001. Com o objetivo de evitar novos ataques terroristas, o conjunto de leis, institucionalizava o monitoramento virtual maciço de qualquer cidadão americano. Segundo Bandeira (2009, p. 729), foi uma ofensiva tão grande contra os direitos civis, com implicações práticas "que poderia ser usado contra qualquer tendência política que praticasse a desobediência civil".

Com o discurso da necessidade de se combater o terrorismo, o governo estadunidense legalizou o monitoramento de ligações telefônicas, e-mails e

\footnotetext{
21 Técnica de afogamento simulado, onde o indivíduo fica deitado em uma prancha, com um pano cobrindo as suas vias respiratórias, joga-se água no pano para que a respiração seja interrompida, simulando assim o afogamento.

22 Como se pode verificar em G1 (2008).
} 
RODRIGUES, Danilo Pontes. Doutrina Bush e violência em In the Shadow of no Towers de Art Spiegelman. Domínios da imagem, v. 13, n. 24, p. 122-156, jan./jun. 2019.

acesso ao movimento bancário de organizações e indivíduos sem a devida autorização judicial.

Tal atitude, na prática, além de autorizar o governo a invadir a esfera privada da população, criou um clima de constante medo de um possível novo ataque pudesse ser executado a qualquer instante. Justamente para evitar que os terroristas descobrissem as medidas antiterroristas do Estado, haveria a necessidade do sigilo das ações, os cidadãos comuns ficaram reféns das informações passadas para a mídia "e tudo isso forma o caldo de cultura ideal para teorias conspiratórias e paranoia social generalizada" (ŽlŽEK, 2003, p. 53).

Portanto, mais do que mudar as medidas do governo Bush, tanto em nível internacional, quanto nacional, os atentados do 11 de Setembro foram acontecimentos marcantes, seja pelo ataque ao território estadunidense, de maneira inédita até então, ou pela forma que as pessoas enxergam o Oriente que será sensivelmente abalado a partir de então.

\section{Considerações finais}

Art Spiegelman, longe de ser um quadrinista que apresenta em sua obra expressões simplórias, optou ao abordar o tema dos atentados terroristas do 11 de setembro não só como uma forma de relato e registro de sua experiência junto à sua esposa na ânsia de localizar sua filha, Nadja, mas para retratar o desmoronamento das torres gêmeas do World Trade center. Portanto apresentou críticas diretas ao governo estadunidense, assim como a sociedade americana.

Optamos por fazer uma análise discursiva da obra, dentro de uma perspectiva teórica do que foi proposto por Douglas Kellner - para a concepção da mídia como um meio de disputa de interesses - e do que Michel Foucault propôs sobre discursos gráficos. 
RODRIGUES, Danilo Pontes. Doutrina Bush e violência em In the Shadow of no Towers de Art Spiegelman. Domínios da imagem, v. 13, n. 24, p. 122-156, jan./jun. 2019.

Apresentamos uma discussão acerca das medidas apresentadas pelo governo Bush, entendemos que tais medidas não surgiram somente como resposta imediata aos atentados, mas dentro de um modelo de política internacional, intervencionista e unilateral, que se desenhava ao longo da década de 1990. Os atentados do 11 de setembro surgiram de forma inesperada, pegando o governo e a população despreparados, resultando na cobrança por respostas partindo do povo.

$\mathrm{Em}$ In the shadow of no towers, Spiegelman criticou o medo exacerbado instaurado após a queda das torres, mas mais do que isso, o quadrinista criticou as decisões do governo Bush, seja no atropelo das liberdades individuais, possibilitadas pelo Patriot Act, assim como o uso de violência promovido pelos Estados Unidos.

Violência esta, criticada e analisada por diversos autores que viram as prisões promovidas de forma arbitrária, com a desculpa de se evitar novos atentados, ou por se tratarem de possíveis terroristas, precisavam ser capturados e punidos de imediato, deixando de lado seus direitos.

Outro aspecto que analisamos foi o discurso da doutrina Bush, aproveitando do cenário posto em prática, como a invasão aos territórios de países produtores de petróleo, como o Iraque, justificando a guerra partindo de uma falsa alegação de o país ser detentor de armas de destruição em massa.

Portanto, tendo em vista o tema do dossiê, compreendemos os Estados Unidos de George W. Bush não como um país autoritário, mas como um governo que possuiu medidas autoritárias. Spiegelman fez um retrato emotivo e ácido acerca do período vivenciado, quadrinista renomado, utilizou a linguagem das HQs para representar suas impressões e aversões ao governo e à sociedade estadunidense. 
RODRIGUES, Danilo Pontes. Doutrina Bush e violência em In the Shadow of no Towers de Art Spiegelman. Domínios da imagem, v. 13, n. 24, p. 122-156, jan./jun. 2019.

\section{REFERÊNCIAS}

1. Fontes analisadas

SPIEGELMAN, Art. À Sombra das Torres Ausentes. Tradução de Antonio de Macedo Soares - São Paulo: Companhia das Letras, 2004.

In the Shadow of no Towers. New York: Pantheon Books 2004.

2. Bibliografia

BANDEIRA, L. A. M. Formação do Império Americano: da guerra contra a Espanha à guerra no Iraque. Rio de Janeiro: Civilização Brasileira. Terceira Edição. 2009.

BARROS, T.S.; TORRES, A.R.R.; PEREIRA, Cícero. Autoritarismo e adesão a sistemas de valores psicossociais. Psico-USF, v. 14, n. 1, p. 47-57, jan./abr. 2009.

BBC. 11 de Setembro: 5 teorias de conspiração, 2011. Disponível em: <http://www.bbc.com/portuguese/noticias/2011/08/110829_11 desetembro_† eorias_cc.shtml>. Acesso em: 09 jan. 2017.

BUSH, George W. President Delivers State of the Union Address. 2002a. Disponível em <http://georgewbushwhitehouse.archives.gov/news/releases/2002/01/20020129-11.html> Acesso em 10 mar. 2019.

CHOMSKY, Noam. 11 de setembro. Tradução de Luiz Antonio Aguiar. 3. ed. Rio de Janeiro: Bertrand Brasil, 2002.

CHARTIER, Roger. A História Cultural: Entre práticas e representações. Rio de Janeiro: Editora Bertrand Brasil, 1990.

COSTA-MATA H. T. Dólar, petróleo e novas práticas de comércio internacional. Economía, Sociedad y Territorio, Toluca, v. 11, n 37, p. 707-728, 2011.

DOSSE, François. O renascimento do acontecimento: Um desafio para o historiador. São Paulo: Editora UNESP, 2013.

ECO, Umberto. Apocalípticos e Integrados. São Paulo: Perspectivas, 2006.

FOUCAULT, Michel. A arqueologia do saber. Tradução de Luiz Felipe Baeta Neves. $7^{\circ}$ Ed. Rio de Janeiro: Forense Universitária, 2008. 
RODRIGUES, Danilo Pontes. Doutrina Bush e violência em In the Shadow of no Towers de Art Spiegelman. Domínios da imagem, v. 13, n. 24, p. 122-156, jan./jun. 2019.

FUKUYAMA, Francis. O dilema Americano: Democracia, poder e o legado do neoconservadorismo. São Paulo: Rocco, 2006.

GOIDANICH, Hiron Cardoso; KLEINERT, André. Enciclopédia dos quadrinhos. Porto Alegre: L\&PM, 2014.

HOBSBAWM, Eric. Globalização, democracia e terrorismo. Tradução de José Viegas. São Paulo: Companhia das Letras, 2007.

JUNG, C.G. Os arquétipos e inconsciente coletivo. Tradução de Maria Luíza Appy, Dora Mariana R. Ferreira da Silva. Petrópolis: Vozes, 2000.

KARNAL, Leandro; [et al.] História dos Estados Unidos: das origens ao século XXI. São Paulo: Contexto, 2008.

KELLNER, Douglas. A Cultura da Mídia - Estudos Culturais: identidade e política entre o moderno e o pós-moderno. Tradução de Ivone Castilho Benedetti. Bauru: Edusc, 2001.

LOSURDO, Domenico. A linguagem do império: léxico da ideologia estadunidense. Tradução de Jaime A. Clasen. São Paulo: Boitempo, 2010.

PECEQUILO, Cristina Soreanu. Os Estados Unidos e o Século XXI. Rio de Janeiro: Elsevier, 2012.

PULITZER. 1992 Pulitzer Prizes. 2016. Disponível em:

<http://www.pulitzer.org/prize-winners-by-year/1992>. Acesso em: 30 Maio. 2019.

PURDY, Sean. O século Americano. IN: KARNAL, Leandro; [et al.] História dos Estados Unidos: das origens ao século XXI. São Paulo: Contexto, 2008.

RICUPERO, Rubens. O mundo após o 11 de setembro: a perda da inocência. Tempo social, v. 15, n. 2, p. 9-30, 2003.

RODRIGUES, Danilo Pontes. Estados Unidos pós 11 de setembro na história em quadrinhos In the shadow of no towers de Art Spiegelman (2001-2004).

Dissertação (Mestrado em História) - Universidade Estadual de Londrina, Londrina, 2017.

SPIEGELMAN, Art. Maus II: A Survivor's Tale II: And Here My Troubles Began. New York: Pantheon Books, 1992.

Maus: A Survivor's Tale I. My Father Bleeds History. New York: Pantheon Books, 1986. 
RODRIGUES, Danilo Pontes. Doutrina Bush e violência em In the Shadow of no Towers de Art Spiegelman. Domínios da imagem, v. 13, n. 24, p. 122-156, jan./jun. 2019.

TERRA. Drones, 2013. Disponível em:

<http://www.terra.com.br/noticias/infograficos/drones/>. Acesso em: 11 jan. 2017.

VERVAELE, J.A.E. A legislação anti-terrorista nos Estados Unidos: Um direito penal do inimigo?. Revista eletrônica de direito penal e política criminal UFRGS, v. 2, n. 1, p. 29-67, 2014.

WRIGHT, Lawrence. O vulto das torres: a Al-Qaeda e o caminho até o 11/9. Tradução de Ivo Koryłowski. São Paulo: Companhia das Letras, 2007.

YODASLAIR. The Katzenjammer Kids, 1998. Disponível em:

<http://www.yodaslair.com/dumboozle/katzies/katzdex.html>. Acesso em: 26 jan. 2017.

ŽlŽEK, Slavoj. Bem-vindo ao deserto do Real!: cinco ensaios sobre o 11 de Setembro e datas relacionadas. Tradução de Paulo Cezar Castanheira. São Paulo: Boitempo Editorial, 2003. 